\title{
PERAN PENDIDIKAN DAN PENGENALAN SISTEM EKONOMI SYARIAH KEPADA GENERASI MUDA DI ERA PERKEMBANGAN EKONOMI SYARIAH
}

\author{
SUMADI \\ STIE - AAS Surakarta \\ Email: sumadi@stie-aas.ac.id
}

\begin{abstract}
This study aims to determine the extent of the role of education and teaching of Islamic economics to the younger generation towards the younger generation in the era of increasingly massive Islamic economic development. The role of education and teaching of Islamic economics as well as business practices based on sharia principles today is no longer a necessity, but has become a reality and is increasingly widespread. Economic institutions and Islamic business products are emerging and growing in various parts of the world, even among non-Muslim communities. Likewise training and education that prepares personnel for it. In the academic arena, scientific studies on the concept of Islamic economics also continue to roll and deepen. This is a result of the weakness of the existing economic system that is not able to prosper the community, on the other hand the occurrence of a dichotomy in the education system that seems to belong only to the economics faculty in terms of economics is the fulfillment of human needs in its life, so that Islamic economic education should be introduced to all young people, especially the Muslim generation. Based on the explanation above, it is obvious that the development of Islamic economic practices in various aspects is so rapid that it is very necessary to prepare a young generation of Islamic economics that can maintain and continue the existence of Islamic economics. Government support is getting better and accommodating towards the development of Islamic economic practices.
\end{abstract}

Keywords: education, the development of Islamic economics, the younger generation

\section{PENDAHULUAN}

Peran pendidikan dan pengajaran ekonomi Islam serta praktik bisnis berdasarkan prinsip syariah dewasa ini tidak lagi merupakan keniscayaan, melainkan sudah menjadi kenyataan dan semakin marak. Lembaga ekonomi dan produk-produk bisnis Islami bermunculan dan tumbuh di berbagai belahan bumi, bahkan di tengah masyarakat nonmuslim. Begitu pula pelatihan dan pendidikan yang menyiapkan tenaga-tenaga untuk itu. Di kancah akademis, kajian-kajian ilmiah mengenai konsep ekonomi Islam juga terus bergulir dan kian mendalam. Hal ini akibat dari lemahnya sistem ekonomi yang telah ada tidak mampu mensejahterakan masyarakat, di pihak lain terjadinya dikotomi dalam sistem pendidikan yang seolah ekonomi ini hanya milik dari fakultas ekonomi saja pada hal ekonomi merupakan pemenuhan kebutuhan manusia dalam hidupnya, sehingga mestinya pendidikan ekonomi islam perlu diperkenalkan pada semua generasi muda khususnya generasi muslim, bahkan akan lebih baik apabila pendidikan ekonomi islam ini 
diperkenalkan sejak dini yaitu dari sekolah dasar, hal ini penting karena akan berdampak pada perilaku dimasa yang akan datang. Mengingat penduduk Indonesia mayoritas beragama islam apabila tidak diperkenalkan ekonomi islam sejak dini maka akibatnya adalah mereka tidak mengerti ekonomi seperti apa yang harus dilakukan, maka tidak heran di negara yang mayoritas penduduknya muslim tetapi dalam perilaku ekonomi keseharianya adalah keluar dari agama yang mereka anut Maka sistem perekonomian syariah menjadi harapan dan bisa dipertimbangkan mana sistem ekonomi yang baik dan harus dilaksanakan agar kesejahteraan masyarakat bisa terwujud.

Oleh karena itu sangatlah penting pemahaman mendasar terkait paham-paham ekonomi yang ada di dunia ini diberikan kepada generasi saat ini, agar kemudian mereka berfikir dan paham bahwa ekonomi syariah adalah sistem ekonomi terbaik yang ada di dunia ini yang akan mensejahterakan umat baik muslim dan non muslim sehingga Islam menjadi rahmat bagi semesta alam.

\section{KAJIAN TEORI}

\section{Ekonomi Kapitalisme}

Paham Kapitalisme berasal dari Inggris abad 18, kemudian menyebar ke Eropa Barat dan Amerika Utara. Sebagai akibat dari perlawanan terhadap ajaran gereja, tumbuh aliran pemikiran liberalisme di negara Eropa Barat. Aliran ini kemudian merambah ke segala bidang termasuk bidang ekonomi. Dasar filosofis pemikiran ekonomi Kapitalis bersumber dari tulisan Adam Smith dalam bukunya An Inquiry into the Nature and Causes of the Wealth of Nations yang ditulis pada tahun 1776. Isi buku tersebut sarat dengan pemikiran tingkah laku ekonomi masyarakat, yang kemudian menjadi sistem ekonomi, dan mengakar menjadi ideologi yang mencerminkan gaya hidup (way of life).

Menurut Smith, manusia melakukan kegiatan ekonomi adalah karena dorongan kepentingan pribadi, yang bertindak sebagai tenaga pendorong dan membimbing manusia mengerjakan apa saja asal masyarakat bersedia membayar "Bukan berkat kemurahan tukang daging, tukang pembuat bir, atau tukang pembuat roti kita dapat makan siang," kata Smith "akan tetapi karena mereka memperhatikan kepentingan pribadi mereka. Kita berbicara bukan kepada rasa perikemanusiaan mereka, melainkan pada cinta mereka kepada diri mereka sendiri, dan jangan sekali-kali berbicara tentang keperluan kita, melainkan tentang keuntungan mereka.” (Robert L. Heilbroner: 1986,). Motif kepentingan individu yang didorong oleh filsafat liberalisme kemudian melahirkan sistem ekonomi pasar bebas, pada melahirkan ekonomi Kapitalis.

Milton H. Spencer (1977), dalam bukunya Contemporary Economics: "Kapitalisme merupakan sebuah sistem organisasi ekonomi yang dicirikan oleh hak milik privat (individu) atas alat-alat produksi dan distribusi (tanah, pabrik-pabrik, jalan-jalan kereta api, dan sebagainya) dan pemanfaatannya untuk mencapai laba dalam kondisi yang sangat kompetitif." Hak milik swasta merupakan elemen paling utama dari kapitalisme. Pemberian hak pemilikan atas harta kekayaan memenuhi tiga macam fungsi ekonomi penting. Para individu memperoleh perangsang agar harta mereka dapat dimanfaatkan seproduktif mungkin. Hal ini sangat mempengaruhi distribusi kekayaan serta pendapatan karena, setiap individu diperkenankan untuk menghimpun harta dan 
memberikannya kepada para ahli waris secara mutlak apabila mereka meninggal dunia. Ia memungkinkan laju pertukaran yang tinggi, karena mereka memiliki hak pemilikan atas barang sebelum hak tersebut dapat dialihkan kepada pihak lain.

Dengan demikian kapitalisme sangat erat hubungannya dengan pengejaran kepentingan individu. Bagi Smith bila setiap individu diperbolehkan mengejar kepentingannya sendiri tanpa adanya campur tangan pihak pemerintah, maka ia seakan-akan dibimbing oleh tangan yang tak nampak (the invisible hand), untuk mencapai yang terbaik pada masyarakat. Kebebasan ekonomi tersebut juga diilhami oleh pendapat Legendre yang ditanya oleh Menteri keuangan Perancis pada masa pemerintahan Louis XIV pada akhir abad ke 17, yakni Jean Bapiste Colbert. Bagaimana kiranya pemerintah dapat membantu dunia usaha, Legendre menjawab: "Laissez nous faire" (jangan mengganggu kita, kata ini dikenal kemudian sebagai laissez faire. Dewasa ini prinsip laissez faire diartikan sebagai tiadanya intervensi pemerintah sehingga timbulah: individualisme ekonomi dan kebebasan ekonomi.

Dalam sistem ekonomi kapitalis berlaku "Free Fight Liberalism" (sistem persaingan bebas). Siapa yang memiliki dan mampu menggunakan kekuatan modal (Capital) secara efektif, efisien dan rpoduktif akan memenangkan pertarungan dalam bisnis. Paham yang mengagungkan kekuatan modal sebagai syarat untuk memenangkan pertarungan ekonomi disebut sebagai Capitalisme. Ekonomi konvensional di bawah dominasi kapitalisme saat ini sedang menghadapi masa krisis dan re-evaluasi. Sebagaimana disebut di atas, kapitalisme menghadapi kritikan dari berbagai penjuru. Mulai dari Karl Max sampai pada era tahun 1940-an,1950-an, 1960an, bahkan di awal abad 21 kritikan tersebut semakin tajam dan meluas. seperti Joseph Schumpeter, Daniel Bell, Irving Kristol, Gunnar Myrdal, Paul Omerod, Umar Ibrahim Vadillo, Critovan Buarque, sampai kepada Joseph Stigliz.

Banyak indikasi kegagalan kapitalisme, karena: pertama, Ekonomi konvensional yang berlandaskan pada sistem ribawi, ternyata semakin menciptakan ketimpangan pendapatan yang hebat dan ketidak-adilan ekonomi. Kedua, Ekonomi kapitalisme juga telah menciptakan krisis moneter dan ekonomi di banyak negara. Di bawah sistem kapitalisme, krisis demi krisi terjadi terus menerus, sejak tahun 1923, 1930, 1940, 1970, 1980, 1990, 1997 bahkan hingga saat ini. Banyak negara senantiasa terancam krisis susulan di masa depan jika sistem kapitalisme terus dipertahankan. Ketiga, Ekonomi kapitalisme banyak melakukan kesalahan dalam sejumlah premisnya, terutama rasionalitas ekonomi yang telah mengabaikan moral dimensi moral.

\section{Ekonomi Sosialisme}

Dalam kehidupan sehari-hari istilah sosialisme digunakan dalam banyak arti. Istilah sosialisme selain digunakan untuk menunjukkan sistem ekonomi, juga digunakan untuk menunjukkan aliran filsafat, ideologi, cita-cita, ajaran-ajaran atau gerakan. Sosialisme sebagai gerakan ekonomi muncul sebagai perlawanan terhadap ketidak adilan yang timbul dari sistem kapitalisme. John Stuart Mill (1806-1873), menyebutkan sebutan sosialisme menunjukkan kegiatan untuk menolong orang-orang yang tidak beruntung dan tertindas dengan sedikit tergantung dari 
bantuan pemerintah. Sosialisme juga diartikan sebagai bentuk perekonomian di mana pemerintah bertindak sebagai pihak yang dapat dipercaya oleh masyarakat, dan menasionalisasikan industri besar dan strategis seperti pertambangan, jalan-, dan jembatan, kereta api, serta cabang-cabang produk lain yang menyangkut hajat hidup orang banyak. Dalam bentuk lengkap sosialisme melibatkan pemilikan semua alat produksi, termasuk di dalamnya tanah pertanian oleh negara, dan menghilangkan milik swasta (Brinton:1981). Dalam masyarakat sosialis hal yang menonjol adalah kolektivisme atau rasa kerbersamaan. Untuk mewujudkan rasa kebersamaan ini, alakosi produksi dan cara pendistribusian semua sumber ekonomi diatur oleh negara.

\section{Ekonomi Komunisme}

Komunisme muncul sebagai aliran ekonomi, ibarat anak haram yang tidak disukai oleh kaum Kapitalis. Aliran ekstrim yang muncul dengan tujuan yang sama dengan sosialisme, sering lebih bersifat gerakan ideologis dan mencoba hendak mendobrak sistem kapitalisme dan sistem lain yang telah mapan. Karl Marx sebagai kampiun komunis, sosok yang amat membenci Kapitalisme ini merupakan korban dan saksi sejarah, betapa ia melihat anak-anak dan wanita-wanita -termasuk keluarganya yang di eksploitir para kapitalis, sementara hasil jerih payah mereka dinikmati oleh para pemilik modal yang disebutnya kaum Bourjuis. Di ilhami pendapat Hegel yang menyatakan bahwa perubahan historis merupakan hasil kekuatan yang bertentangan satu sama lain. Pertentangan tersebut pada dasarnya bersifat ekonomis atau materialistis, dengan demikian faktor ekonomi menurut Marx mejadi sebab pokok terjadinya perubahan.

Kata Komunisme secara historis sering digunakan untuk menggambarkan sistem sosial dimana barang dimiliki secara bersama dan didistribusikan untuk kepentingan bersama sesuai dengan kebutuhan masing-masing anggota masyarakat. Produksi dan konsumsi bersama berdasarkan kapasitas ini merupakan hal pokok dalam mendefinisikan paham komunis. Kendatipun tujuan sosialisme dan komunisme sama, tetapi dalam mencapai tujuan tersebut sangat berbeda. Komunisme adalah bentuk paling ekstrem dari sosialisme. Bentuk sistem perekonomian yang didasarkan atas sistem, di mana segala sesuatunya serba dikomando, karena dalam sistem komunisme negara adalah penguasa mutlak, perekonomian komunis disebut pula sebagai "sistem ekonomi totaliter", menunjuk pada suatu kondisi sosial di mana pemerintah main paksa dalam menjalankan kebijakannya, meskipun dipercayakan pada asosiasi-asosiasi dalam sistem sosial kemasyarakatan yang ada. Sistem ekonomi totaliter dalam praktiknya berubah menjadi sistem otoriter, dimana sumber ekonomi dikuasai oleh segelintir elite yang disebut sebagai polit biro yang terdiri dari elite-elite penguasa partai Komunis.

\section{Ekonomi Fasisme}

Fasisme berasal dari filsafat radikal yang muncul dari revolusi industri yakni sindikatisme. Eksponen sindikatisme adalah George Sorel (1847-1922). Penganjur sindikatisme menginginkan reorganisasi masyarakat menjadi: asosiasi-asosiasi yang mencakup seluruh industri, atau sindikat- 
sindikat pekerja. Dianjurkan agar ada sindikat-sindikat pabrik baja yang dimiliki dan dioperasikan oleh para pekerja di dalam industri batu bara, dan demikian pula halnya pada industri-industri lain. Dengan demikian sindikat-sindikat yang ada pada dasarnya merupakan serikat buruh yang akan menggantikan negara. Dalam sistem ekonomi fasisme, pemerintah melakukan pengendalian dalam bidang produksi, sedangkan kekayaan dimiliki oleh pihak swasta. Dalam praktik Fasisme dan Komunisme adalah dua gejala dari penyakit yang sama. Keduanya sering dikelompokkan sebagai sistem totaliter. Keduanya sama dalam hal pemerintahan, yaitu kediktatoran satu partai.

\section{Ekonomi Syariah}

Ilmu ekonomi Islam atau ekonomi syari'ah merupakan ilmu pengetahuan sosial yang mempelajari masalah ekonomi rakyat yang dilhami oleh nilai-nilai Islam. Sejauh mengenai masalah pokok, hampir tidak terdapat perbedaan apapun antara ilmu ekonomi Islam dan ilmu ekonomi modern. Andaipun ada perbedaan itu terletak pada sifat dan volumenya (M. Abdul Mannan; 1993). Itulah sebabnya mengapa perbedaan pokok antara kedua sistem ilmu ekonomi dapat dikemukakan dengan memperhatikan penanganan masalah pilihan. Dalam ilmu ekonomi modern masalah pilihan ini sangat tergantung pada macam tingkah masing-masing individu. Mereka mungkin juga tidak memperhitungkan persyaratan masyarakat, namun dalam ilmu ekonomi Islam, kita tidaklah berada dalam kedudukan untuk mendistribusikan sumber-sumber semau kita. Dalam hal ini ada pembatasan berdasarkan ketetapan Al-Sunnah atas tenaga individu. Dalam Islam, kesejahteraan sosial dapat dimaksimalkan jika sumber daya ekonomi juga dialokasikan sedemikian rupa, sehingga dengan pengaturan kembali keadaannya, tidak seorang pun lebih baik dengan menjadikan orang lain lebih buruk di dalam kerangka Al-Sunnah. Perlu diingat, ilmu ekonomi Islam tidak dapat berdiri netral di antara tujuan yang berbeda-beda. Kegiatan membuat dan menjual minuman alkohol dapat dikatakan bisnis yang baik dalam sistem ekonomi modern. Namun hal ini tidak dimungkinkan dalam Islam.

Indonesia sebagai satu diantara Negara di dunia telah menjadikan ekonomi neoklasik sebagai basis teoretis kebijakan pembangunan ekonomi setidak selama Indonesia merdeka (62 tahun), ternyata telah gagal mewujudkan cita-cita ekonomi bangsa seperti yang diamanatkan UndangUndang Dasar 1945, terutama dalam menyediakan lapangan kerja yang layak bagi kehidupan rakyatnya. Hal ini mungkin karena tidak menyadari bahwa individualisme, materialisme dan pandangan tentang manusia yang terdapat dalam pihak ekonomi neoklasik tidak sejalan dan bahkan bertentangan dengan nilai-nilai pokok dari Pembukaan Undang-Undang Dasar 1945.

Berbagai fakta kegagalan pembangunan perekonomian Indonesia, sebagaimana diamanahkan dalam pembukaan Undang-undang dasar 1945, antara lain disebutkan bahwa pemerintahan Negara dibentuk "untuk memajukan kesejahteraan umum. Lapangan kerja merupakan salah satu ukuran utama yang perlu dipertimbangkan. Lapangan kerja yang mencukupi merupakan sarana utama bagi masyarakat untuk memperoleh pendapatan dengan halal. Lapangan kerja menyangkut harga diri, dan pengangguran yang berkepanjangan akan berarti hilangnya harga diri selain menurunnya tingkat hidup bagi yang bersangkutan. Oleh karena itu pengangguran harus dihapus melalui kebijakan Negara yang tepat dalam menciptakan lapangan kerja. 
Mengapa Indonesia gagal mengupayakan kesejahteraan rakyatnya. Kegagalan berkaitan dengan paham sosial ekonomi yang dianut sebagai dasar operasional penentuan kebijakan dalam pembangunan, utamanya pembangunan ekonomi. Paham ini disebut sebagai paham ekonomi neoklasik. Sangat menonjolnya individualisme dalam pola berpikir paham neoklasik, yang selanjutnya ekonomi neoklasik ini mengejewantahkan individualisme dalam bentuk yang ekstrim dan individualistik mempersulit upaya peningkatan efisiensi, karena efisiensi membutuhkan partisipasi semua pihak dalam berbagai dimensi kegiatan. Kondisi di atas diperparah dengan mengemukanya paham materialisme diantara individu, yang secara langsung menolak adannya Tuhan Yang Maha Esa (Moser, P.K., Trout, J.D., Editors, 1995) dan hal ini bertentangan dengan Undang-Undang dasar 1945. sementara itu masyarakat beragama, yang dalam hal ini yang beragama Islam, jelas menolak paham tersebut. Firman Allah Subhanahuata'ala dalam Al-Qur'an (17: 85): "Dan mereka bertanya kepadamu tentang ruh. Katakanlah: "Ruh itu termasuk urusan Tuhan-ku, dan tidaklah kamu diberi pengetahuan melainkan sedikit”.

Sementara itu dalam perekonomian yang semakin terbuka, pengaruh global semakin terasa. Bukan saja perbankkan islam yang berhubungan dengan perbankan konvensional, namun juga bagian-bagian lain yang ada di Indonesia saling berhubungan dengan bagian yang ada di luar negeri. Bisnis yang bernafaskan Islam mulai marak muncul di mana-mana, seperti bisnis disektor keuangan: Bank, Leasing, Modal Ventura, Asuransi, Pasar Modal, Dana Pensiun, Pegadaian, Kartu Plastik, Anjak Piutang, Lembaga Amil Zakat, koperasi, dan bahkan bisnis lain yang berhubungan langsung dengan kebutuhan masyarakat seperti: bisnis waralaba, rumah makan, hotel, pendidikan dan lainlain, namun kepesatan tumbuh dan berkembangnya bisnis Islam ini tidak diimbangi dengan upaya penyediaan SDM yang sesuai untuk mendukung keberhasilan bisnis tersebut. Berbicara tentang ekonomi Islam, perhatian biasanya tertuju pada bank Islam, atau di Indonesia disebut Bank Syariah, hal ini tidak sepenuhnya salah, namun demikian juga tidak sepenuhnya benar. "Ekonomi Islam tidak hanya tentang bank Islam, namun, bank Islam merupakan pintu gerbang untuk mengembangkan ekonomi Islam," sebagai contoh: jaminan kepuasan pelanggan (customer satisfaction) sebagai salah satu wujud ekonomi Islam. "Jika kita memproduksi dan menjual barang bermutu baik, harga bersaing, dan pelayanan purna jual yang memuaskan, hal ini merupakan wujud ekonomi Islam," Barang bermutu baik, harus sesuai dengan keadaan yang seharusnya. Misalnya, madu lebah. "Sekarang kita sulit mencari madu lebah asli, karena di mana-mana banyak dijajakan madu lebah, akan tetapi mendapatkan yang asli sulit diperoleh (meskipun promosinya gencar) akan tetapi praktiknya telah dicampur dengan berbagai pemanis. Jika demikian halnya, bukan madu lebah asli namanya, dan berarti tidak Islami”. Upaya menjaga lingkungan dan pembangunan hutan secara berkelanjutan juga merupakan bagian dari ekonomi Islam. "Mereka yang merusak hutan, sehingga berakibat tanah longsor dan banjir yang menelan korban manusia dan harta benda, jelas tidak Islami."

Dengan demikian inti dari ekonomi Islam adalah menyangkut kemaslahatan dan kerelaan kedua belah pihak dalam bertransaksi. "Hal ini mencakup berbagai bidang, seperti pemasaran, lembaga keuangan dan jasa, serta industri yang berkelanjutan, perkebunan, kehutanan, kelautan. 
Demikian pula perangkat besertifikat mutu manajemen, seperti ISO, BAN, Sertifikasi Risk Management, Sertfikasi Guru dapat menjadi bagian dari ekonomi Islam." Pembentukan manusia sesuai dengan kualifikasi yang dibutuhkan untuk bisnis Islam memerlukan waktu yang relatif lama, perlu perencanaan yang baik sehingga pada waktunya dapat memenuhi kebutuhan SDM untuk lembaga tersebut. Sementara itu perpindahan SDM antara bank saat ini dirasakan cukup tinggi, sebagai akibat lemahnya pengkaderan untuk mengimbangi percepatan pertumbuhan perbankan ataupun lembaga keuangan lainnya. Seharusnya pembajakan tidak akan terjadi bila kaderisasi dilaksanakan secara berkesinambungan sehingga mampu memenuhi percepatan pertumbuhan berbagai bidang usaha.

Untuk pengkaderan ini lembaga-lembaga tersebut menghadapi kendala karena keterbatasan pengetahuan dan kemampuan untuk menyelenggarakan pendidikan dan pelatihan yang sesuai dengan kebutuhan, sedangkan bila pengkaderan tersebut dipercayakan kepada lembaga training professional yang khusus untuk materi bisnis Islam, jumlah lembaga penyelenggaranyapun sangat terbatas. Demikian pula halnya dengan lembaga pendidikan tinggi yang menyelenggarakan program bisnis/ekonomi Islam jumlahnya relatif sedikit, serta kurikulum yang digunakanpun tertinggal jauh dibandingkan kepesatan pertumbuhan bisnisnya.

Akhirnya dapat kita maklum bersama, mengapa perilaku kita jauh dengan harapan dari ekonomi Islam yang sebenarnya, dan bahkan kita malah justru berperilaku non Islami sejak dari tidur sampai akan tidur kembali . Hal demikian tidak lain karena kita sudah terjerumus pada budaya non Islami yang sudah tertanam sejak dini , karena tidak pernah didapatkan pengenalan sistem ekonomi Islam sejak dini, itulah inti kesalahan yang sebenarnya, keadaan ini akan menjadi lebih parah apabila dibarengi dengan generasi yang tidak mengerti agama islam /islamic phobia generation.

\section{HASIL DAN PEMBAHASAN}

\section{Perkembangan Industri Keuangan Syariah di Indonesia}

Kondisi perekonomian domestik maupun internasional mutakhir, terutama setelah timbulnya krisis keuangan global September 2008 di USA lalu dan krisis moneter pada pertengahan 1997 di Indonesia dan negara-negara lain dengan segala dampaknya seperti likuidasi atas 69 bank swasta nasional serta menggunungnya biaya rekapitalisasi perbankan yang mencapai Rp 635 triliun, menuntut kita untuk mencermatinya secara serius dan dengan sudut pandang yang harus berbeda. Apapun, kondisi tersebut membuktikan bahwa sistem perekonomian kapitalis makin mengalami kesulitan untuk menghantarkan masyarakat menuju keadaan yang dicita-citakannya. Pada akhirnya, sorotan terhadap "kehampaan" tatanan ekonomi dunia memaksa berbagai kalangan menengok kepada sistem ekonomi alternatif, yakni sistem ekonomi Islam yang kendati secara faktual belum terujud, secara intelektual sedang dalam pengkajian intensif, tapi secara imani diyakini mampu memberikan solusi. Bahkan praktik dalam berbagai bidang ekonomi Islam juga sudah dimulai di Indonesia sejak beberapa tahun lalu. 
Tepat dua tahun setelah munculnya krisis keuangan Asia, dibuka Bank Syari'ah Mandiri (BSM) sebagai bank syari'ah milik pemerintah pertama di tanah air. Langkah BSM ini disusul oleh Bank IFI yang membuka cabang syari'ah, demikian juga cabang syari'ah Bank Bukopin di Aceh. Di antara bank milik pemerintah daerah, Bank Jabar adalah bank PEMDA yang pertama memiliki cabang syari'ah. Setelah melihat respons yang cukup positif, dua bank pemerintah lainnya, BNI-46 dan BRI, dan bank swasta (Bank Danamon), juga masuk ke industri perbankan yang baru ini. Hingga pada Februari 2008, telah terdapat 3 Bank Umum Syariah, 13 unit Usaha Syariah Bank Umum, 14 unit usaha Syariah BPD, 3 Bank Kustodian Syariah, 114 lebih Bank Perkreditan Rakyat Syariah. Untuk 2008, BI meyakini industri bank syariah masih menikmati periode high growth. Oleh karena itu, BI mematok pangsa aset lima persen sebagai direction dan anchor bagi industri perbankan syariah. Dalam program akselerasinya tahun ini, BI menerbitkan sejumlah kebijakan lanjutan. Dengan berbagai kebijakan tersebut, BI memproyeksikan pertumbuhan aset, dana pihak ketiga (DPK), dan pembiayaan selama 2008 mampu mencapai masing-masing sebesar Rp 91,6 triliun, Rp 73,3 triliun, dan Rp 68,9 triliun. Di samping itu, perkembangan lembaga keuangan mikro Syariah yang di Indonesia disebut sebagai Baitul Mal Wat-Tamwil (BMT) sangat pesat. Dalam prakteknya BMT melaksanakan dua jenis kegiatan yaitu Baitul Tamwil dan Baitul Mal. Baitul Tamwil bergiat mengembangkan usaha-usaha produktif dan investasi dalam meningkatkan kualitas kegiatan pengusaha kecil bawah dan kecil dengan mendorong kegiatan menabung dan menunjang pembiayaan ekonomi. Sedangkan baitul Mal menerima titipan zakat, infaq, dan shadaqah serta menjalankannya sesuai dengan peraturan dan amanahnya.

Pada pertengahan 2006, menurut berita di harian nasional Republika menyebutkan bahwa BMT itu beragam dari sisi aset, yakni ada yang besar dan kecil. Di antaranya ada yang mencapai aset sampai Rp 30 miliar. Tetapi ada pula yang asetnya yang sebesar Rp 100 juta. Pada pertengahan 2006, dari 3000 BMT yang ada, diperkirakan total asetnya senilai Rp 2 triliun dengan perputaran dana mencapai Rp1,8 triliun. Akhir 2007, jumlah BMT mencapai 4000-an BMT. Sementara itu, Ketua Asosiasi BMT se-Indonesia (Absindo) Aries Mufti mengatakan, target ke depan yang akan dicapai secara bertahap itu adalah mewujudkan setiap desa memiliki satu BMT dan saat ini diperkirakan ada 67.700 desa diseluruh Indonesia. Pada tahap awal di tahun 2010 ditargetkan terwujud 10 ribu unit BMT. Bahkan Wapres Yusuf Kalla mengharapkan agar pada tahun 2010, target pengembangan BMT sebanyak 10 ribu BMT dapat tercapai. ${ }^{4}$ Prospek pengembangan BMT cukup besar mengingat lembaga BUMN atau perusahaan swasta lainnya pada umumnya memiliki kerjasama untuk memberdayakan ekonomi masyarakat bawah dan hal itu membutuhkan lembaga keuangan mikro seperti BMT untuk bekerjasama.

Praktek ekonomi Islam dalam aspek asuransi Syariah di Indonesia dimulai sejak tahun 1994 yang ditandai dengan pendirian PT Asuransi Takaful Indonesia. Setelah itu, jasa asuransi yang dikelola berdasarkan prinsip syariah mulai dikembangkan baik oleh lembaga asuransi full syariah ataupun perusahaan asuransi yang mengembangkan divisi syariah. Keberadaan asuransi syariah didorong oleh anjuran adanya upaya-upaya menuju kepada perencanaan masa depan dengan sistem proteksi yang dikenal dalam mekanisme asuransi dan keyakinan sebagian masyarakat bahwa 
pengelolaan asuransi harus sejalan dengan kaidah dan prinsip syariah khususnya berkaitan dengan pengelolaan keuangan yang bebas riba, maysir dan gharar.

Perbedaan mendasar dalam produk asuransi syariah adalah cara pengelolaan risiko yang menganut azas tolong menolong dengan membagi risiko diantara peserta asuransi (risk sharing). Selain perbedaan cara pengelolaan risiko, ada perbedaan cara mengelola unsur tabungan produk asuransi. Pengelolaan dana pada asuransi jiwa syariah menganut investasi syariah dan terbebas dari unsur ribawi. Sepanjang 2005, asuransi syariah masih menunjukkan perkembangan yang cukup pesat. Sebanyak sepuluh perusahaan asuransi konvensional membuka cabang syariah, terdiri atas delapan perusahaan asuransi kerugian dan satu perusahaan reasuransi. ${ }^{5}$ Dengan demikian, sampai akhir 2007 terdapat 37 perusahaan asuransi syariah, 3 reasuransi syariah, 5 broker asuransi dan reasuransi Syariah. ${ }^{6}$ Perkembangan yang menggembirakan juga terjadi di pasar modal, yaitu dengan hadirnya reksadana syari'ah PT Danareksa dan Investment management syari'ah PT PNM (persero). Hingga akhir 2007, terdapat 18 reksadana Syariah dan 29 Obligasi Syariah \& Medium Term Notes (MTN). Berdasarkan gambaran di atas, perkembangan praktek ekonomi Islam di Indonesia memberikan harapan besar yang menumbuhkan optimisme bagi umat Islam untuk terus berupaya mengembangkan ekonomi Islam di Indonesia, terlebih lagi setelah lahirnya UU Perbankan Syariah dan Surat Berharga Syariah Negara. Aspek-aspek ekonomi Islam yang dipraktekkan juga telah meluas. Berdasarkan data tersebut di atas, telah terdapat ratusan lembaga keuangan dan bisnis syariah dengan ribuan kantor pelayanan syariah di Indonesia. Namun menjadi pengetahuan bersama, bahwa kecepatan pertumbuhan bisnis syariah tidak diikuti dengan penyediaan SDM yang mencukupi.

\section{KESIMPULAN}

Berasarkan paparan tersebut di atas, nyatalah bahwa perkembangan praktik ekonomi Islam dalam berbagai aspeknya yang begitu pesat maka sangat perlunya mempersiapkan generasi muda ekonomi Islam yang dapat menjaga dan meneruskan eksistensi ekonomi Islam. Dukungan pemerintah yang semakin baik dan akomodatif terhadap perkembangan praktik ekonomi Islam, terutama lahirnya UU Perbankan Syariah dan UU Surat Berharga Syariah Negara pada tahun 2008 lalu memberikan harapan baru yang lebih cerah tentang masa depan praktik ekonomi Islam di Indonesia. Oleh karena itu, ketersediaan SDM unggul yang mendukung pengembangan dan perluasan praktik ekonomi Islam di Indonesia merupakan suatu keniscayaan. Dalam rangka itu, telah banyak institusi pendidikan yang berlomba mempersiapkan SDM sesuai dengan kebutuhan industri dan bisnis yang merupakan implementasi sistem ekonomi Islam. Dengan upaya tersebut, insyaAllah masa depan pendidikan ekonomi Islam Indonesia ke depan semakin prospektif berkat dukungan semakin luasnya aspek praktik ekonomi Islam dan dukungan positif pemerintah dalam bentuk regulasi dan pembinaan. 


\section{UCAPAN TERIMAKASIH}

Terimakasih kami haturkan kepada Dewan Redaksi Jurnal Edunomika yang telah memberikan kesempatan, sehingga tulisan saya bisa diterbitkan.

\section{DAFTAR PUSTAKA}

Al-Qur'an Terjemahan Departemen Agama RI

An Nabhani, Taqiyyudin. 1990. An Nizham Al Iqtishadi fi Al Islam. (Beirut : Darul Ummah).

Kahf, M., 1995, Ekonomi Islam, PustakaPelajar, Yogyakarta

Karim, A. Ir. , 2007. Ekonomi Mikro Islam, edisi ketiga, Rajawali Pers, Jakarta

Marton, Saad, Said, (2004), Ekonomi Islam Ditengah Krisis Ekonomi Global, Zikrul Hakim, Jakarta

Metwally, (1995), Teori dan model ekonomi islam. PT Bangkit Daya Insana, Jakarta

Nasution, M.E., Huda, N., dkk (2006). Pengenalan Ekslusif Ilmuekonomi Islam, Kencana Prenada Group, Jakarta

P3EI, 2008, Ekonomi Islam, Rajawali Pers, Jakarta

Rahardja, P. dan Mandala, M., 2004, Teori Ekonomi Mikro: Suatu Pengantar, edisi ketiga, Lembaga Penerbit FE UI, Jakarta.

Sukirno, S., 2009, Mikro Ekonomi: Teori Pengantar, edisi ketiga, Rajawali Pers, Jakarta

Sumadi (2015), Kasus Pencucian Uang Dalam Tinjauan Sistem Ekonomi Islam, Jurnal Ilmiah Ekonomi Islam Vol. 3 (03)

Sumadi (2017), Alternatif Sistem Ekonomi Islam Untuk Indonesia Yang Lebih Sejahtera, Jurnal Ilmiah Ekonomi Islam Vol. 1 (02)

Weber, Max, The Protestant Ethics and the Spirit of Capitalism, Charles Scribner's Sons, New York, 1958

Veithzal Rivai akselerasi pengembangan pendidikan tinggi ekonomi islam di indonesia

Winardi, 1986, Kapitalisme Versus Sosialisme, (Bandung: Remadja Karya). 